\title{
The Positive Role of Shame for Post-exilic Returnees in Ezra/Nehemiah
}

\author{
Bin Kang (Biblical Seminary of the Philippines)
}

\begin{abstract}
While shame is often cast in a negative light as a response accompanied by destructive forces in modern culture, this article examines a different phenomenon and argues that shame plays an important positive role for post-exilic returnees in Ezra/Nehemiah. Shame can be progressive and edifying if it is oriented in the right direction.
\end{abstract}

This article surveys key shame terms in Ezra/Nehemiah by examining בוש I I In Ezra 8:22, כלם In Ezra 9:6-7, מרפה in Neh 1:3; 2:17 and בוזה in Neh 3:36 (Eng. 4:4) for their semantics and concludes that shame plays a positive role in social control for the post-exilic returnees. Shame, in each of these cases, motivated the people of God not for bad but for good; it contributed to the rebuilding of the temple of the Lord, the rebuilding of the wall, and the restoration of a holy people to the Lord in the midst of fierce opposition.

KEYWORDS: Shame; Positive role; Disgrace; Reproach; Contempt; Exile; Returnees; Holy Seed; Rebuilding; Ezra; Nehemiah

\section{A INTRODUCTION}

The notion of honour and shame was pervasive in the ancient biblical world (both the OT and NT periods), and it is not an exaggeration to say that the culture of honour and shame governed people's underlying system of thought, speech, and behaviour. ${ }^{1}$ While most present-day readers may perceive of honour and shame as a psychological state reflecting a person's character, the ancient biblical world valued these cultural components as determinations of one's identity and social status. ${ }^{2}$ It seems fair to say that modern readers have often downplayed the value

* Submitted: 02/09/2019; peer-reviewed: 19/05/2020; accepted: 24/06/2020. Bin Kang "The Positive Role of Shame for Post-exilic Returnees in Ezra/Nehemiah," Old Testament Essays 33 no. 2 (2020): 250 - 265. DOI: https://doi.org/10.17159/23123621/2020/v33n2a6.

1 Johannes Pedersen, Israel, Its Life and Culture (London: Oxford University Press, 1926), 213-44. See also Lyn M. Bechtel, "Shame as a Sanction of Social Control in Biblical Israel: Judicial, Political, and Social Shaming," JSOT 49 (1991): 47-76. For an understanding of honour and shame culture in the NT period, consult, e.g., David A. deSilva, Honor, Patronage, Kinship \& Purity: Unlocking New Testament Culture (Downers Grove, IL: InterVarsity Press, 2000), 23-42.

2 Ronald A. Simkins, "Honor, Shame," in Eerdmans Dictionary of the Bible, ed. David Noel Freedman (Grand Rapids: Eerdmans, 2000), 603. 
of reading the biblical text against a backdrop of honour and shame. ${ }^{3}$ However, recent scholarship has paid more attention to anthropological studies of the Old Testament. $^{4}$

Shame is often considered a "negative self-evaluation." Indeed, shame as an emotion of "negative self-evaluation" can in fact lead to destructive forces. Amnon's rape of Tamar (2 Sam 13:7-14) and his subsequent rejection of her (2 Sam 13:15-18) brought great shame to Tamar as she lost her virginity and honour. It seems that Tamar was never able to recover from this shaming experience (2 Sam 13:20, "a desolate, devastated woman"). However, at least some biblical scholars have begun to recognize that shame also has a potentially positive role to play. For example, Jacqueline E. Lapsley has pointed out that shame plays an important and positive role in understanding Ezekiel's message to the exiled community. The recognition of Israel's shamed status, as shown in the metaphor of an adulterous woman in Ezekiel 16 and Ezekiel 23, should guide the community to a correct evaluation of their past shamed practices, orient them to the good, and ultimately lead them to a restoration of the relationship with $\mathrm{YHWH}^{6}$

3 Victor H. Matthews, Don C. Benjamin, and Claudia Camp, eds., Semeia 68: Honor and Shame in the World of the Bible (Atlanta: Society of Biblical Literature, 1994), 23113.

4 The Semeia volume mentioned in the previous footnote was certainly an important step in the study of honour and shame in the Old Testament. For essays in the Semeia volume directly related to Old Testament studies, see Dianne Bergant, "“My Beloved Is Mine and I Am His' (Song 2:16): The Song of Songs and Honor and Shame," Semeia 68 (1994): 23-40; Ronald A. Simkins, "Return to Yahweh': Honor and Shame in Joel," Semeia 68 (1994): 41-54; Gary Stansell, "Honor and Shame in the David Narratives," Semeia 68 (1994): 55-79; For examples of other works on honour and shame in the Old Testament since the time of the Semeia volume, see Saul M. Olyan, "Honor, Shame, and Covenant Relations in Ancient Israel and Its Environment," JBL 115 (1996): 201228; Timothy S. Laniak, Shame and Honor in the Book of Esther (SBLDS 165; Atlanta: Scholars Press, 1998); Shane Kirkpatrick, Competing for Honor: A Social-Scientific Reading of Daniel 1-6 (Leiden: Brill, 2005); Andrew M. Mbuvi, "The Ancient Mediterranean Values of Honour and Shame as a Hermeneutical Lens for Reading the Book of Job," OTE 23 (2010): 752-768; Johanna Stiebert, "Shame and Prophecy: Approaches Past and Present," BibInt 8 (2000): 255-75; Joshua Moon, "Honor and Shame in Hosea's Marriages," JSOT 39 (2015): 335-51.

5 Stiebert, "Shame and Prophecy," 257.

6 Jacqueline E. Lapsley, "Shame and Self-Knowledge: The Positive Role of Shame in Ezekiel's View of the Moral Self," in The Book of Ezekiel: Theological and Anthropological Perspectives (eds. Margaret S. Odell and John T. Strong; Atlanta: Society of Biblical Literature, 2000), 143-73. Bechtel also sees that the fear of shame functions as a sanction of social control in biblical Israel in a variety of contexts: formal judicial shaming, formal political shaming, and informal social shaming. Bechtel presents selected examples of the uses of shaming in biblical texts to illustrate that the 
In this article, I want to explore further the positive role of shame as portrayed by the biblical text and to argue in particular that shame plays a significantly positive role for purposes of social control among the post-exilic returnees in Ezra/Nehemiah. To be more specific, shame functions in a positive way in the post-exilic Israelite community to drive them in their participation in the rebuilding of the Temple of the Lord, their involvement in the rebuilding of the wall, and their reestablishment of a holy people to the Lord. In order to achieve the purpose for this article, I want to begin by discussing the definitions of honour and shame and then examine some key semantic terms, specifically those that are most relevant to the notion of shame in Ezra-Nehemiah. Though this article does not address the function of shame in 1 and 2 Chronicles (which together with Ezra-Nehemiah is often viewed as the larger Chronistic history), ${ }^{7}$ it would not be surprising that such books also conceivably present a positive role for shame. ${ }^{8}$

\section{B DEFINITION OF HONOUR AND SHAME}

The definitions of honour and shame call for further clarification. What are these two social components? This is not a simple question to answer. To take a shortcut, since honour and shame are words of dichotomy in the Hebrew Bible, if we could define honour properly, then shame would be an antonym of it. Halvor Moxnes sees honour as "fundamentally the public recognition of one's social standing." Johannes Pedersen says otherwise, claiming that "Honor is not that which the man himself or others, with more or less justice, think of him. Honor is that which actually fills the soul and keeps it upright." 10 The following definition from Jerome H. Neyrey presents a more balanced view: honour refers to "the worth or value of persons both in their own eyes and in the eyes of their

sanction of shaming plays a significant role in the honour-shame oriented society portrayed through the biblical text. See Bechtel, "Shame as a Sanction of Social Control in Biblical Israel," 47-76; idem, "The Perception of Shame Within the Divine-human Relationship in Biblical Israel," in Uncovering Ancient Stones; Essays in Memory of H. Neil Richardson (ed. Lewis M. Hopfe; Winona Lake, IN: Eisenbrauns, 1994), 79-92. As much as shaming appears to be a social concern, Bechtel also presents shaming as an important tie between YHWH and his people as a religious concern; it was YHWH's covenant obligation to protect the righteous from undeserved shame.

7 Lester L. Grabbe, A History of the Jews and Judaism in the Second Temple Period. Vol. 1, Yehud, A History of the Persian Province of Judah (LSTS 47; London: T\&T Clark, 2004), 71.

8 For example, pertaining to Sennacherib's attack against Jerusalem (2 Chr 32:1-23), Hezekiah the king was provoked by the humiliating letters that Sennacherib delivered to taunt (לחרף) YHWH, the God of Israel (2 Chr 32:17). In this case, the potential suffering of shame spurred Hezekiah on to cry to God in prayer and eventually God granted him a sweeping victory over the Assyrians.

9 Halvor Moxnes, "Honor and Shame," BTB 23 (1993): 167-76.

10 Pedersen, Israel, its Life and Culture, 213. 
village or neighborhood." 11 If a person is not able to maintain his honour, or his worth is not recognized by his community, then this person is shamed. In other words, shame is the rejection and denial of the recognition of one's value.

Such a definition also matches the usage of terms for honour and shame in biblical Hebrew. The biblical term translated as "honour" comes from the Hebrew word כבד. It derives from the basic meaning of "heavy," and thus metaphorically has a large range of meaning conveying "burdensome, difficult, important, precious or glorious." 13 Thus, a person with honour is one with value and significance. Nevertheless, terms that describe shame are far more prevalent. ${ }^{14}$ In semantic antonymy to קבל I, esteemed, vile," 16 denotes "worthlessness," in other words, a depreciation of one's value. Indeed, semantic investigations of such terms can supplement a "finer definition of honour or shame."17

11 Jerome H. Neyrey, Honor and Shame in the Gospel of Matthew (Louisville: Westminster John Knox, 1998), 5. Similarly, honour is defined as "the positive value of a person in his or her own eyes plus the positive appreciation of that person in the eyes of his or her social group." See Bruce J. Malina and Jerome H. Neyrey, "Honor and Shame in Luke Acts: Pivotal Values of the Mediterranean World," in The Social World of Luke-Acts: Models for Interpretation (ed. Jerome H. Neyrey; Peabody, MA: Hendrickson, 1991), 25.

12 Other terms to denote honour could be גלה ("be high"), הדר ("splendour"), כשא (") ("raise up"), כלל ("perfection"), and ("favour").

13 Weinfeld, "כבלד," TDOT 7:13-38.

14 Terms that align with shame could be חרף I ("reproach"), חלל I ("profane"), בוש I ("shame"), כלם ("to humiliate, to be humiliated") and ("to be terrified"). Some of

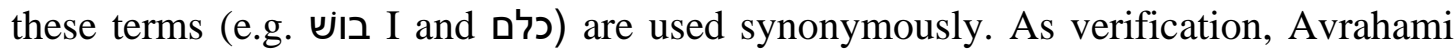
showcases בוש I ("shame") and other synonyms as semantically parallel in Psalms. See Yael Avrahami, "בוש in the Psalms-Shame or Disappointment?" JSOT 34 (2010): 300-302. According to Jumper's calculation, בוש I and its derivatives occur 170 times in the OT. See James Nicholas Jumper, "Honor and Shame in the Deuteronomic Covenant and the Deuteronomistic Presentation of the Davidic Covenant" (PhD Thesis., Harvard University, 2013), 93. The root בוש I is perhaps the most commonly recognized term related to shame.

15 The semantic antonymy between קלל כבד I is perhaps best understood by the story of Eli. God condemned the priest Eli with the assertion that "you honoured ותכבד) your sons more than me [YHWH]" (1 Sam 2:29) by tolerating the iniquities of his sons (i.e., robbing the raw meat waiting to be boiled as an offering to God and engaging in illicit sexual relationships with women serving at the tent of meeting). Consequentially, God declares, in judgment, that "those who honour me I will honour (אכבד), and those who despise me shall be insignificant (disdained, יקלו)" (1 Sam 2:30).

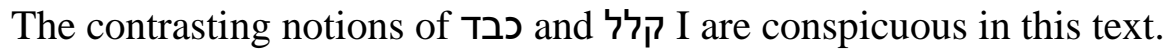

16 See " קלל I," $D C H$ 7:256-58. I refer to $D C H$ for Hebrew terms with homonymic values in this article.

17 Avrahami, "בוש in the Psalms," 313. 
Although shame is often compared with guilt, a distinction between the two is often debated among scholars. ${ }^{18}$ Since the distinction between shame and guilt is not the focus of this article, I simply want to acknowledge that the term "shame" in this article is used in a different way from "guilt." I recognize that the difference between shame and guilt is both subtle and important.

Having laid these foundations, we will turn next to the most prominent passages with explicit expressions of the notion of "shame" in Ezra/Nehemiah.

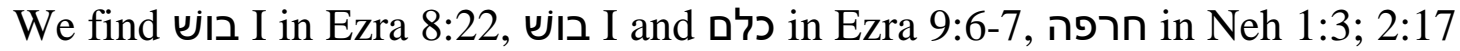
and בוזה in Neh 3:36 (Eng. 4:4) as the most conspicuous references portraying shame in these books. In passages such as these, shame oriented the people of God not for bad but for good; the fear of further disgrace and degradation among the nations stimulated the returnees to cry out to God for his grace and mercy for the rebuilding of the temple, for the rebuilding of the wall, and for the formation of a holy community in Jerusalem in the midst of opposition. Hopefully, an inductive approach utilizing references concerning shame in Ezra/Nehemiah can

18 From an anthropological perspective, it is perhaps predominantly true that Asian cultures are "shame" driven whereas the Western world is "guilt" oriented, though every culture contains elements of both shame and guilt. Shame derives primarily from external social sanctions within a group, whereas guilt is a response to a transgression of a moral law, against a predominantly internalized valued system. See Timothy C. Tennent, Theology in the Context of World Christianity (Grand Rapids: Zondervan, 2007), 78-82.

From a psychological viewpoint, guilt is defined as a response to internalized standards, and shame as a response to external harmful experiences such as ridicule and scorn of others. See Helen Merrell Lynd, On Shame and the Search for Identity (1958; repr., London: Routledge, 1999), 21.

From a biblical perspective, Stiebert regards "shame" and "guilt" as two different categories of emotions: "shame" as an emotion in response to "negative selfevaluation" and "guilt" as an emotion in response to the transgression of laws. There is still a debate as to whether one should separate shame and guilt in practice. See Stiebert, "Shame and Prophecy," 255-59. Likewise, Bechtel defines "shame" as a "failure or inadequacy to reach or live up to a socio-parental goal or ideal" and "guilt" as "the act of transgression." Shame often has an impact on "who a person is" while guilt often points to the aftermath of a certain action that is wrong. See Bechtel, "Shame as a Sanction of Social Control," 48-53. I prefer to concur with Bechtel's analysis of the difference between shame and guilt.

After reviewing recent studies in psychology and anthropology on this topic, $\mathrm{Wu}$ summarizes the discussion by stating that "it seems reasonable to view both shame and guilt as part of a common concept sphere denoting an actual or potential ascription of disconnection between expectation and reality." Wu integrates both shame and guilt as a disconnection between expectation and reality. The difference is that such an ascription may be given by the person himself, the community, or by God. See Daniel Wu, Honor, Shame, and Guilt: Social-Scientific Approaches to the Book of Ezekiel (Winona Lake, IN: Eisenbrauns, 2016), 57. 
contribute to the broader examination of the role and function of shame in the honour-shame oriented biblical world.

\section{I In Ezra 8:22}

An excellent example of the discussion of shame within Ezra/Nehemiah is found

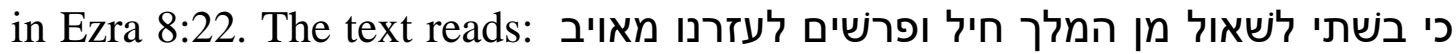
בדרך כי אמרנו למלך לאמר יד־אלהינו על כל מבקים לנישיו לטבה ועזו ואפו על כל עזביו ("For I was ashamed to ask the king for soldiers and horsemen to protect us from the enemies on the way, for we said to the king, 'The hand of our God is for good upon all those who seek him but his power and his wrath is against all who forsake him""). ${ }^{19}$ Though some are inclined to translate בוש with a different shade of meaning as "to fail to," ${ }^{20}$ I still side with most of the translations, which

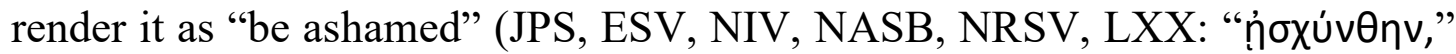
from the lemma $\alpha i \sigma \chi v ́ v \omega)$. The former translation indeed conveys the sense of rejection of the king's offer, but the context here suggests that the issue of shame was still prominent in Ezra's motive in not seeking the king's help for an armed escort. $^{21}$

Ezra realized the risk of the long and perilous journey ${ }^{22}$ as he led the people back to Jerusalem, especially when they were accompanied by women, infants, treasuries of gold and silver, and offerings for the temple (Ezra 8:26-27). Plus, tensions escalated as rivals of the Jews were also notified of Ezra's plan to return in advance (Ezra 7:21-24; 8:31). Under such circumstances, it was said that Ezra proclaimed a fast among his people at the river Ahava; the purpose of the fast was to seek God's protection for a straight (safe) journey (דרך ישרה, Ezra 8:21). Obviously, the communal fasting was to show their dependence on God through prayer.

19 Translations are mine throughout this article.

20 With the translation "to fail to," the verse presents it as if it was due to Ezra's lack of initiative that he failed to ask the king for armed soldiers to escort them to Jerusalem. See Avrahami, "בוש in the Psalms," 311. Similarly, DCH treats it with a different homonymic value (בוש III) to mean "be hesitant" (בוש",DCH 2:132; cf. also "to hesitate," “בוש," HALOT, 117). However, Avrahami' assumption to ascribe to בוש I the meaning "disappointment" in some lamentation Psalms is partly grounded in her

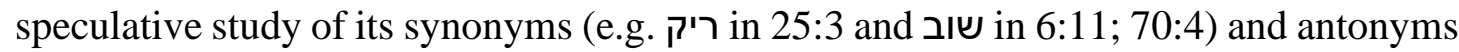
(e.g., בקש in 69:7, 31:18). Words put together in a sentence do not mean that they are, by default, synonyms or antonyms. Her use of these terms in such a manner is problematic.

21 Fensham also identifies v. 22 as one of Ezra's motives of his supplication to God. See F. Charles Fensham, The Books of Ezra and Nehemiah (NICOT; Grand Rapids: Eerdmans, 1982), 117.

22 It could have taken up to four months to travel from Babylon to Jerusalem. See Joseph Too Shao and Rosa Ching Shao, Ezra-Nehemiah (Asia Bible Commentary; Manila: OMF Literature, 2007), 77. 
What made the fasting so unique was the following additional statement in Ezra 8:22. Though a request for an armed escort from the king seemed the safest way for Ezra to avoid any foreseeable dangers on the journey, he was ashamed of (בשתתי) doing so before the Persian emperor, for he had earlier boasted before the king of God's divine protection and care for his people. Given the benevolent assistance of Artaxerxes as portrayed in Ezra 7:11-26, a persuasive theory is that the king would have offered Ezra an armed escort for protection (as in the case of Nehemiah [Neh 2:9]), especially in light of the large amount of treasure (Ezra 8:26-27) to be carried. ${ }^{23}$ However, Ezra graciously declined it out of his faith in God, while perhaps also showing signs of a lack of deep consideration and calculation for the safety of the journey.

Now if Ezra were to bring up the request before the king, it would be as if to signal a message to the king that he and the people of Israel were not confident that the God of Israel was powerful enough to protect them from danger en route as said earlier. It was a moment of a test of faith. ${ }^{24}$ Asking for the king's armed support, on this occasion, would diminish the reputation and sovereignty of the God of Israel before a pagan king and would amount to Ezra slapping himself in the face. Thus, it was because of the potential suffering of shame that Ezra declined to ask for help despite the perils of the journey.

Nevertheless, the fear of shame pushed Ezra and the returnees to face the challenge by turning to God alone for help through fervent fasting and devoted prayer. This fasting and prayer, in some sense, was triggered in part by the fear of shame, in conjunction with the prospect of potential danger. Such a relationship can also be seen by the explanatory causal ${ }^{25}$ conjunction marker ('כ, "for") at the beginning of 8:22. In other words, the fear of shame stimulated the whole community, led by Ezra, to cry to God in fasting and prayers for divine

23 Admittedly, Persian royal assistance to the returnees was not "philanthropy" but a benefit offered out of their own interests and propaganda. For instance, the Cyrus Cylinder, as an ancient relic, attributes the return of the "gods" of specified places with their people to their original dwelling-places (the Jewish return to Jerusalem not being specified in the text) to the virtues of Marduk, the god of Babylon. See Amélie Kuhrt, "The Cyrus Cylinder and Achaemenid Imperial Policy," JSOT 25 (1983): 87. However, according to the editors of Ezra-Nehemiah, all the royal decrees were still prompted by YHWH's divine provision. See Gregory Goswell, "The Attitude to the Persians in EzraNehemiah," TJ 32 (2001): 192-98. For a similar vein in stressing God's authority toward Persian lordship, see Daniel Smith-Christopher, A Biblical Theology of Exile (Overtures to Biblical Theology; Minneapolis: Augsburg Fortress Publishers, 2002), 45.

24 H. G. M. Williamson, Ezra-Nehemiah (WBC 16; Waco, TX: Word Books, 1985), 118.

25 This is to differentiate it from the ordinary causality of "because." See Paul Joüon and Takamitsu Muraoka, A Grammar of Biblical Hebrew (Subsidia Biblica 27; Rome: Editrice Pontificio Instituto Biblico, 2006), §170 (p. 599). 
protection. Eventually, God answered their prayers and granted them a safe journey to Jerusalem, protecting them from enemy ambush (8:31).

\section{2 בלו I I I Ezra 9:6-7}

Chapter 9 of Ezra opens up with attention given to the sensitive problem of mixed marriages among the returnees in Jerusalem (Ezra 9:1-2); such intermarriages threatened the existence of Israel as a chosen "Holy Seed"26 זרע הקדש, Ezra 9:2) and, by extension, their religious purity in worship to YHWH. Such an offence was in direct opposition to the Mosaic law (Deut 7:1-8). When the problem was brought to Ezra, he responded with a strong sense of awe and lament because of the sins of the people. Modern readers perhaps do not understand why Ezra had to be so strict in dealing with the problem of intermarriage. However, the history of Israel demonstrated that the Israelites lost their identity when they were assimilated into other ethnic groups and became compromised in their monotheistic faith. Formation of identity in the post-exilic community was given serious consideration after their experience of exile. ${ }^{27}$ With a contrite spirit, Ezra, along with the repentant people, offered a long prayer of confessions (9:1-15). The prayer was a "theological reflection" 28 on the history of Israel ending with the tragedy of exile (also Neh 9:5-37). Ezra 9:6-7, as part of the confessional prayer, is an interesting passage where we find shame and guilt overlapping. ${ }^{29}$

26 The term זרע הקדש can also possibly be considered as an allusion to Isa 6:13. See J. G. McConville, "Ezra-Nehemiah and the Fulfilment of Prophecy," VT 36 (1986): 218-22. Such a term describes a strong sense of pride for the Israelites as God's "holy people" (Lev 20:26; Exod 19:5-6; Deut 7:7; Isa 62:12). Mixed marriages would have threatened the "purity" of Israel's existence.

27 See Bonifácio Paulo, "The Abolition of Intermarriage in Ezra 10 and the Ethnic Identity of the Postexilic Judean Community: A Hermeneutic Study" (Th.M. dissertation, Stellenbosch University, 2014), 168-70; see also Jacob M. Myers, EzraNehemiah, Anchor Bible (New York: Doubleday, 1965), 77. For a recent book that addresses this issue, see Willa M., Johnson, The Holy Seed Has Been Defiled: The Interethnic Marriage Dilemma in Ezra 9-10 (HBM 33; Sheffield: Sheffield Phoenix Press, 2011).

28 Jerry Hwang, "How Long Will My Glory be Reproach?" Honour and Shame in Old Testament Lament Traditions," OTE 30 (2017): 699.

29 Sin leads to shame as well as guilt. Ezra's confession of עונתינו ("our iniquities) and אשמתנו ("our guilt") was perhaps guilt-driven in 9:6-7; i.e., the Israelites had transgressed against the covenant law of God and thus suffered the covenant curses (Deuteronomy 28) before their enemies. The confession of guilt is also noted by Michael W. Duggan, "Ezra 9:6-15 within Its Literary Setting," in Seeking the Favor of God: The Origins of Penitential Prayer in Second Temple Judaism (ed. Mark J. Boda, Daniel K. Falk, and Rodney A. Werline; Atlanta: Society of Biblical Literature, 2006), 169. 
The prayer opens with a strong acknowledgment of shame: ואמרה אלה בשתי ונכלמתי להרים אלהי פני אליך (and I said to my God, "I am ashamed and humiliated to raise up, oh my God, my face to you" [Ezra 9:6]). It is typical to see the root כלם I, since it often appears in parallel with I I in the Old Testament to express utter shame. ${ }^{30}$ Ezra's public acknowledgement of shame was on a collective level on behalf of the people, though personally he did nothing to bring shame upon himself. What is striking is the possible intertextual reading and use of terms from an early exilic context. Earlier, the prophet Ezekiel had urged the גולה community to repent in shame (בושו והכלמו, Ezek 36:32) in view of God's unconditional grace (Ezek 36:24-30) notwithstanding it was their shamelessness that had resulted in God's holy name (שם קדשי) being profaned (חללוהו) among the nations (Ezek 36:21).

After quickly going through the rebellious history of Israel that ended with the nation in exile (Ezra 9:6b-7), Ezra returned again to the present reality of Israel as an "open shame" (ובבשת פנים, Ezra 9:7b) before the nations. ${ }^{32}$ Shame from the past "pillage and humiliation" before foreign kings still carried into the current time as if the punishment of captivity were still felt in the present ( כהיום (הזה ("slaves") was a term to denote a shamed identity of social standing for the returnees. ${ }^{34}$ Ezra lamented (Ezra 9:9) that "we are slaves (עבדים) in our slavery (ובעבדתנו)." He bewailed that Israel had come to be in a debased position before the royal Persian power. When one recalls that Israel's premium status was given as God's chosen "treasured possession" (סלה הס, Exod 19:5-6; Deut 7:6) above all other peoples, the sense of shame would only intensify with her dramatic fall from o to מגלה shame and humiliation encapsulate Ezra's penitential prayer.

\footnotetext{
30 “כלם," HALOT, 480.

31 Hwang, "How long will my Glory be Reproach?" 700.

32 The phrase בששת פנים describes shame in a publicly observable manner and refers to the loss of public reputation; thus it is the "loss of face" with public disgrace or

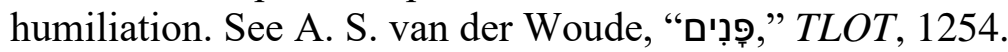

33 See Shao, Ezra-Nehemiah, 88. Perhaps the situation of the returnees in Jerusalem was no better than the exilic condition. Although the returned Israelites were allowed to rebuild the temple (Ezra 6:15), they still found themselves in a lowly position.

34 According to Bechtel, a loss of social position can lead to shame. See Bechtel, "Shame as a Sanction of Social Control," 50.

35 Interestingly, Nehemiah was more sensitive to Israel's shamed status as עבדים in עבדים his prayers. Israel was called to be God's servants (עבדים, Neh 1:10), but now Israel had become the "slaves" (עבדים, Neh 9:36) of the land rather than its master to enjoy its goodness as God had promised to the forefathers. In 9:37, Nehemiah went on to elaborate that Israel was forced to hand over the produce of the land to foreign kings; even their own bodies and livestock were in bondage. Nehemiah's prayer may reflect a Deuteronomic covenant background. See Mark J. Boda, "Praying the Tradition: The Origin and Use of Tradition in Nehemiah 9," TynBul 48 (1997): 182.
} 
The confession of shame and guilt moved the congregation to the repentance of a covenant (נכרת ברית, Ezra 10:3) renewal. A great assembly was gathered to Ezra in confession, weeping, and prayers; and the mention of the presence of "women and children," alongside men within the assembly (Ezra 10:1), indicated that the movement of repentance reached even the grassroots level among the returnees. The people's response of commitment in observing God's law can be seen in the use of the first-person plural ${ }^{36}$ as Shecaniah exhorted his other fellow Israelites to send away the foreign wives and children in their midst (Ezra 10:3). Later the Israelites even took an oath that they would separate from foreign wives (Ezra 10:5), and, despite the heavy rains, a national convocation was called in Jerusalem within three days to implement such a reform (Ezra 10:9-16). Thus, the devout and urgent repentance and commitment, as a response to Ezra's confessional prayer of shame and guilt in Ezra 9:6-7, was constructive in establishing a זרע הקדש among the returnees. To conclude, here we see how shame played a positive role in the formation of a holy community in Jerusalem.

\section{$3 \quad$ ח in Neh $1: 3 ; 2: 17^{37}$}

While Nehemiah was in the citadel of Susa, his brother Hanani, together with some other men, came from Judah and visited him (Neh 1:2). Nehemiah inquired about the conditions of the survivors (הנשאארים) ${ }^{38}$ in Jerusalem. The news he received was heart-grieving: Jerusalem was in "great distress" (ברעה גדלה) and "disgrace" (ובחרפה); even the wall of Jerusalem was broken down and its gates were burned with fire (Neh 1:3). ${ }^{39}$ No further details were provided concerning

36 The use of the first-person plural (Ezra 10:2-4) was to identify with Ezra. See Duggan, "Ezra 9:6-15 within Its Literary Setting," 174.

37 חרפה also occurs in Neh 4:4 and 5:9 wherein it describes the active taunting of Israel's enemies. This article, being selective, does not address these issues. Its verbal form I ("reproach, taunt") also appears in Neh 6:13.

38 Opinions are divided over their identity. Some argue that they belonged to the remnant in Judah that had never suffered the exile in Babylon; others think they were Israelites who returned from Babylon to Jerusalem. But it is more probable that no such distinction was intended in this context, הנשארים may loosely apply to "all surviving Jews in Judah." See Williamson, Ezra-Nehemiah, 171.

39 There is disagreement as to whether the broken wall should be taken as a recent disaster or the destruction of Jerusalem in the time of Nebuchadnezzar (about a hundred and forty years earlier). For those who favour that of 586 B.C., see, e.g., Fensham, The Books of Ezra and Nehemiah, 152. For others who prefer a more recent disaster, see Lester L. Grabbe, Ezra-Nehemiah (Old Testament Readings; London: Routledge, 1998), 38; Loring W. Batten, A Critical and Exegetical Commentary on the Books of Ezra and Nehemiah (New York: Charles Scribner's Sons, 1913), 184. The view of a recent catastrophe seems to be more favourable. 
how Jerusalem was mistreated by her enemies; but given the overt hostility of the opponents (Ezra 4:1-24), such disturbing news would not be surprising.

What was at stake was the national disgrace Israel suffered among the surrounding nations. Jerusalem had become a desolate place with no protection and thus was vulnerable to any foreign raids. Such a "disgrace" may be reminiscent of God's judgment and wrath for Israel's disobedience and faithlessness (Ezek 5:14-15;22:4). Moved by this tragedy of shame and horror, Nehemiah responded with weeping, fasting and a confessional prayer (Neh 1:4). ${ }^{40}$ In the prayer, Nehemiah confessed the sins of the people of Israel in failing to obey God's commandments and asked for mercy in the light of their repentance (שוב, Neh 1:9). Surprisingly, Nehemiah did not sit idly by but rather considered himself as part of God's answer in restoring the honour of Israel. Israel's national disgrace perplexed Nehemiah and prompted him to such a point that he approached the king, Artaxerxes, and asked for his favour and permission to return to Jerusalem for a period of time to rebuild the city (Neh 2:1-5). ${ }^{41}$

Upon his arrival in Jerusalem, Nehemiah scrutinized Jerusalem in the middle of the night, examining the walls that were broken down and the gates that had been destroyed by fire (Neh 2:13). After that, he exhorted the people in Jerusalem to rebuild the ruined walls and gates with the purpose that "we shall no longer be a reproach/disgrace" (ולאי נהיה עוד חרפה, Neh 2:17). Here, חרפה repeats itself by ringing the alarm bell to remind the audience of their shamed status. As Derek Kidner rightly says, "It is the disgrace, not the insecurity of their position, which strikes him." ${ }^{43}$ Such a sense of disgrace would be further foregrounded if one were to realize that Jerusalem was once seen as "the city of the great King" and "the joy of all the earth" (Ps 48:3, Eng. 48:2). Indeed, Israel's national disgrace had been Nehemiah's main concern in his pilgrimage to Jerusalem. Rebuilding the city's walls and gates would be the direct way to keep Israel from being further shamed and thus restored to honour. ${ }^{44}$ Nehemiah was

40 In the light of the time interval mentioned in Neh $1: 1 ; 2: 1$, it took at least three months for Nehemiah to engage in constant fasting and prayers. See Myers, EzraNehemiah, 99.

41 As a cupbearer of the king (1:11b), a distinguished position and status, Nehemiah made a great sacrifice in discharging his service before the king. See Joseph Blenkinsopp, Ezra-Nehemiah (Philadelphia: Westminster, 1988), 212-13.

42 A volitive followed by $w o+$ the prefix conjugation is considered a conjunctivesequential waw to express purpose or result. See IBHS, 39.2.2. Hence, many English translations render the waw as "that" (ESV, KJV, AV) or "so that" (NASB, NRSV, NET).

43 Derek Kidner, Ezra and Nehemiah: An Introduction and Commentary (TOTC; Downers Grove, IL: InterVarsity, 1979), 83.

44 The rebuilding was necessary in order to regain respect after the humiliation suffered and to silence the reproach of the enemies. See Blenkinsopp, Ezra-Nehemiah, 224. 
committed to do so despite the threat and shame inflicted on him by his opponents (Neh 2:19). ${ }^{45}$

To sum up, our investigation shows that the fear of shame (חרפה as a national disgrace) played a positive role in spurring the returnees to rebuild the ruined walls and gates of Jerusalem in the face of intense threats and attacks from their opponents.

\section{4 בוזה In Neh 3:36 (Eng. 4:4)}

The returnees faced increasing opposition from their opponents as they started to rebuild the wall. One of the weapons of the enemies was words hurled with ridicule and shame. Sanballat, one of the opponents, mocked (וילעג, Neh 3:33, Eng. 4:1) the Jews who were rebuilding the wall with stinging sarcasm (Neh 3:34, Eng. 4:2): "What are these feeble Jews doing? Will they restore (the city) for themselves? Will they sacrifice? Will they finish in a day? Will they revive the stones from piles of dust, even these burned ones?" The Jews found themselves to be speechless in answering all these scornful questions. The sharp words brought back the not-far-off history of Jerusalem's shamed destruction in 586 B.C. during the Babylonian invasion, in which the temple of the Lord was set ablaze (2 Kgs 25:9; $2 \mathrm{Chr} 36: 19$ ). In other words, the ridicule may be equivalent to an open note of scorn like this: "If your ancestors were not able to preserve the temple and the city, why are you trying again in vain to build these walls?" Indeed, the following taunt was even more provocative and sarcastic as Tobiah the Ammonite jeered at the Jews (Neh 3:35, Eng. 4:3): "Even what they are building, if a fox goes up on it, it would break down their stone walls." This was to insult the Jews that the wall they built was too weak to withstand the weight of a fox on it. ${ }^{46}$ Such words expressed a scathing disdain for the rebuilding project. The enemies challenged the Jews in the midst of their rebuilding project by hurling insults at them.

The Jews who heard the reproach of the enemies cried to God in an urgent response of prayer. The prayer laments that they had become "(an object of) contempt" (היינו בוזה) before their opponents and asks God to intervene and bring revenge on them for their reproach (חרפתם) accordingly (Neh 3:36, Eng.

45 The opponents mocked (וילעגו) and ridiculed (ויבזו) Nehemiah and the people for the rebuilding project (Neh 2:19). Later on, they continued to try to discredit Nehemiah's reputation (לשם רע) and to reproach (יחרפוני) him (Neh 6:13) in order to obstruct the rebuilding process.

46 See Shao, Ezra-Nehemiah, 142-43.

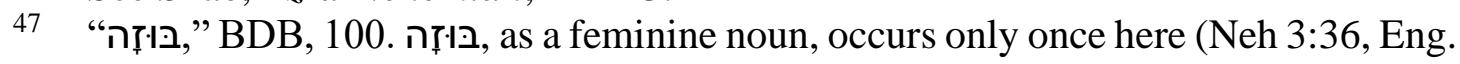
$4: 4)$ in the Scripture. The use of the feminine form is perhaps to establish a wordplay on rhythm with the later word בִּזָּ ("plunder") in the same verse. 
4:4). The prayer itself also verifies that casting shame was the most prominent motive for their utterances.

What is surprising is that the builders did not take the shame hurled against them at a personal level. It was God's purpose to restore Jerusalem and the rebuilding project was a God-initiated task, and thus any opposition against them was tantamount to opposing God. Any shaming against them was an offense to God's holiness and justice. ${ }^{48}$ The Jews acknowledged that God stood on their behalf in the midst of oppositions and tribulations.

The outcome of this shaming encounter was that the people of God became more devoted to doing their work and they were able to build the whole wall to half its height in the shortest possible time (Neh 3:38, Eng. 4:6). Although the opponents attempted to fight against the Jews to obstruct the rebuilding process (Neh 4:2, Eng. 4:8), Nehemiah inspired the people and led them to work fully armed, day and night (Neh 4:7-17, Eng. 4:13-23), until the project came to full completion in just fifty-two days (Neh 6:15).

\section{CONCLUSION}

As much as possible, people seek honour and avoid shame. Counter to the traditional assumption of shame's negative role and function, ${ }^{49}$ this selective inductive study of בוש I in Ezra 8:22, כלם I I I I I Ezra 9:6-7, חרפה in Neh 1:3; 2:17 and בוזה in Neh 3:36 (Eng. 4:4) has repeatedly shown that shame played a positive role in social control for the post-exilic returnees in Ezra/Nehemiah. Shame, in each of these cases, motivated the people of God not for bad but for good; it contributed to the rebuilding of the temple of the Lord, the rebuilding of the wall, and the reestablishment of a holy people to the Lord in the midst of fierce opposition. Shame in an honour/shame culture can be progressive and edifying if it is oriented toward the right direction, i.e., the value of having the right sense of shame. The study also finds that shame functions both at the individual and communal levels in Ezra/Nehemiah.

Churches in Asia, in general, are still very much immersed in the culture of honour and shame. Thus, it is more commonplace for Christians in this part of the world to develop shame in the midst of sufferings. However, shame should not be regarded, by default, as bad and negative. This study has shown that the right sense of shame can be constructive and beneficial to the establishment of God's work and God's people.

\footnotetext{
48 Shao, Ezra-Nehemiah, 144.

49 Shame cultures are often assumed to be primitive, backward, amoral, and lacking in concern. See Bechtel, "Shame as a Sanction of Social Control," 50.
} 


\section{BIBLIOGRAPHY}

Avrahami, Yael. "בוש in the Psalms-Shame or Disappointment?" Journal for the Study of the Old Testament 34 (2010): 295-313. https://doi.org/10.1177/030908 9210363026.

Batten, Loring W. A Critical and Exegetical Commentary on the Books of Ezra and Nehemiah. New York: Charles Scribner's Sons, 1913.

Bechtel, Lyn M. "Shame as a Sanction of Social Control in Biblical Israel: Judicial, Political, and Social Shaming." Journal for the Study of the Old Testament 49 (1991): 47-76. https://doi.org/10.1177/030908929101604903.

. "The Perception of Shame Within the Divine-human Relationship in Biblical Israel." Pages 79-92 in Uncovering Ancient Stones; Essays in Memory of H. Neil Richardson. Edited by Lewis M. Hopfe. Winona Lake, IN: Eisenbrauns, 1994.

Blenkinsopp, Joseph. Ezra-Nehemiah. Philadelphia: The Westminster Press, 1988.

Boda, Mark J. "Praying the Tradition: The Origin and Use of Tradition in Nehemiah 9." Tyndale Bulletin 48 (1997): 179-82. https://doi.org/10.1515/9783110800357.

Botterweck, G. J. and H. Ringgren, eds. Theological Dictionary of the Old Testament. Translated by J. T. Willis, G. W. Bromiley, and D. E. Green. 15 vols. Grand Rapids: Eerdmans, 1974-2006.

Brown, Francis, S.R. Driver, Charles A. Briggs, James Strong, and Wilhelm Gesenius. The Brown-Driver-Briggs Hebrew and English Lexicon: With an Appendix Containing the Biblical Aramaic: Coded with the Numbering System from Strong's Exhaustive Concordance of the Bible. Peabody, MA: Hendrickson Publishers, 1996.

Clines, D.J.A., ed. Dictionary of Classical Hebrew. 8 vols. Sheffield: Sheffield Academic Press: 1993-2011.

deSilva, David A. Honor, Patronage, Kinship \& Purity: Unlocking New Testament Culture. Downers Grove, IL: InterVarsity Press, 2000.

Duggan, Michael W. "Ezra 9:6-15 within Its Literary Setting." Pages 165-75 in Seeking the Favor of God: The Origins of Penitential Prayer in Second Temple Judaism. Edited by Mark J. Boda, Daniel K. Falk, and Rodney A. Werline. Atlanta: Society of Biblical Literature, 2006.

Fensham, F. Charles. The Books of Ezra and Nehemiah. NICOT. Grand Rapids: Eerdmans, 1982.

Goswell, Gregory. "The Attitude to the Persians in Ezra-Nehemiah." Trinity Journal 32 (2001): 191-203.

Grabbe, Lester L. A History of the Jews and Judaism in the Second Temple Period. Vol. 1, Yehud, A History of the Persian Province of Judah. LSTS 47. London: T\&T Clark, 2004.

—. Ezra-Nehemiah. Old Testament Readings. London: Routledge, 1998.

Hwang, Jerry. "How long will my Glory be Reproach?" Honour and Shame in Old Testament Lament Traditions." Old Testament Essays 30 (2017): 684-706. https://doi.org/10.17159/2312-3621/2017/v30n3a9.

Johnson, Willa M., The Holy Seed Has Been Defiled: The Interethnic Marriage Dilemma in Ezra 9-10. HBM 33. Sheffield: Sheffield Phoenix Press, 2011.

Kidner, Derek. Ezra and Nehemiah: An Introduction and Commentary. Downers' Grove: InterVarsity Press, 1979. 
264 Kang, “The Positive Role of Shame," OTE 33/2 (2020): 250-265

Koehler, L., W. Baumgartner, and J.J. Stamm, The Hebrew and Aramaic Lexicon of the Old Testament. Translated and edited under the supervision of M. E. J. Richardson. 4 vols. Leiden: Brill, 1994-1999.

Kuhrt, Amélie. "The Cyrus Cylinder and Achaemenid Imperial Policy." Journal for the Study of the Old Testament 25 (1983): 83-97. https://doi.org/10.1177/030908928300802507.

Kirkpatrick, Shane. Competing for Honor: A Social-Scientific Reading of Daniel 1-6. Leiden: Brill, 2005.

Laniak, Timothy S. Shame and Honor in the Book of Esther. SBL Dissertation Series 165. Atlanta: Scholars Press, 1998.

Lapsley, Jacqueline E. "Shame and Self-Knowledge: The Positive Role of Shame in Ezekiel's View of the Moral Self." Pages 143-73 in The Book of Ezekiel: Theological and Anthropological Perspectives. Edited by Margaret S. Odell and John T. Strong. Atlanta: Society of Biblical Literature, 2000.

Lynd, Helen Merrell. On Shame and the Search for Identity. 1958. Reprinted. London: Routledge, 1999.

Jenni, Ernst and Claus Westermann. Theological Lexicon of the Old Testament. Translated by Mark E. Biddle. 3 vols. Peabody: Hendrickson, 1997.

Joüon, Paul and T. Muraoka. A Grammar of Biblical Hebrew. Subsidia Biblica 27. Roma: Editrice Pontificio Instituto Biblico, 2006.

Jumper, James Nicholas. "Honor and Shame in the Deuteronomic Covenant and the Deuteronomistic Presentation of the Davidic Covenant." Ph.D. thesis., Harvard University, 2013.

Matthews, Victor H., Don C. Benjamin, and Claudia Camp, eds. Semeia 68: Honor and Shame in the World of the Bible. Atlanta: Society of Biblical Literature, 1996.

Mbuvi, Andrew M. "The Ancient Mediterranean Values of Honour and Shame as a Hermeneutical Lens for Reading the Book of Job." Old Testament Essays 23 (2010): 752-68.

McConville, J.G. "Ezra-Nehemiah and the Fulfilment of Prophecy." Vetus Testamentum 36 (1986): 205-24. https://doi.org/10.1163/156853386x00041.

Moon, Joshua. "Honor and Shame in Hosea's Marriages." Journal for the Study of the Old Testament 39 (2015): 335-51. https://doi.org/10.1177/0309089215577592.

Moxnes, Halvor. "Honor and Shame." Biblical Theology Bulletin 23 (1993): 167-76.

Myers, Jacob M. Ezra-Nehemiah. New York: Doubleday, 1965. https://doi.org/10.1177/014610799302300405.

Neyrey, Jerome H. Honor and Shame in the Gospel of Matthew. Louisville: Westminster John Knox Press, 1998.

- ed. The Social World of Luke-Acts: Models for Interpretation. Peabody, MA: Hendrickson, 1991.

Paulo, Bonifácio. "The Abolition of Intermarriage in Ezra 10 and the Ethnic Identity of the Postexilic Judean Community: A Hermeneutic Study." Th.M. dissertation, Stellenbosch University, 2014.

Pedersen, Johannes. Israel, Its Life and Culture. London: Oxford University Press, 1926.

Shao, Joseph Too and Rosa Ching Shao. Ezra-Nehemiah. Asia Bible Commentary Series. Edited by Bruce J. Nicholls. Manila: OMF Literature, 2007.

Simkins, Ronald A. "Honor, Shame." Pages 603-4 in Eerdmans Dictionary of the Bible. Edited by David Noel Freedman. Grand Rapids: Eerdmans, 2000. 
Smith-Christopher, Daniel. A Biblical Theology of Exile. Minneapolis: Augsburg Fortress Publishers, 2002.

Stiebert, Johanna. "Shame and Prophecy: Approaches Past and Present." Biblical Interpretation 8 (2000): 255-75. https://doi.org/10.1163/156851500750096345.

Tennent, Timothy C. Theology in the Context of World Christianity. Grand Rapids: Zondervan, 2007.

Waltke, Bruce K. and M. O'Connor. An Introduction to Biblical Hebrew Syntax. Winona Lake, IN: Eisenbrauns: 1990.

Williamson, H.G.M. Ezra-Nehemiah. Word Biblical Commentary 16. Waco, TX: Word Books, 1985.

Wu, Daniel. Honor, Shame, and Guilt: Social-Scientific Approaches to the Book of Ezekiel. Winona Lake, IN: Eisenbrauns, 2016.

Bin Kang, Ph.D. Candidate in Biblical Studies at the Asia Graduate School of Theology-Philippines, hosted by Biblical Seminary of the Philippines. 77-B Karuhatan Rd, Valenzuela, 1441 Metro Manila, Philippines. Email: omove316@hotmail.com. ORCID ID: https://orcid.org/0000-0002-1089-7654. 